występkami Go obraziłem, za co Go szczerze przepraszam i całym sercem żałuję $e^{66}$. Źródłem takiego jego charakteru i duchowego usposobienia była zawsze żywa dziecięca pobożność, wiara i miłość Boga.

S̄p. Ks. Archutowski umarł sześć lat temu. W pamięci naszej jednak żyje i żyć będzie nadal przez swoje czyny, prace i daleko naprzód wybiegające zamiary ${ }^{12}$ ).

Kraków

Ks. STANISEAW GRZYBEK

\title{
OSOBOWOŚĆ PEDAGOGICZNA CHRYSTUSA
}

I. Chrystus ,jedynym Nuuczycielem".

Już Sokrates był zdania, że w kwestiach najważniejszych zagadnień bytu ludzkiego rozum nie może być jedynym miarodajnym światłem. Stąd pochodzi nieodzowna konieczność zstąpienia samego Boga na ziemię, na którejby żywym słowem i przykładem życia nauczył prawdziwej sprawiedliwości. Poglądy Sokratesa podzielał jego uczeń Platon. W powyższych problemach dwie miał do wyboru drogi. Pierwszą, na którejby sam gruntownie mógł zbadać, jak postępować należy, a jeśliby to było niemożliwe, musiałby wejść na drugą drogę, oparcia się na miarodajnym w tych sprawach autorytecie. Wiara w rozum utalentowanych jednostek może przysporzyć pewnej poręki na bezpieczne przepłynięcie przepastnego oceanu życia. Niemniej jednak bezpieczniej i pewniej odbywa się podróż po wzburzonych falach życia, gdy łódź życia jest w swych częściach bardziej zwarta, trwalsza i odporniejsza przeciwko porywistym i burzliwym wichrom i nawałnicom. Doznaje zaś wzmocnienia wtedy, gdy się człowiek oprze w swych tendencjach życiowych na jakimś objawieniu Bożym (Logon theiov tinos diaporevthenai - Symposion).

Myśli największych mędrców świata hellenistycznego o ponadświatowym nauczycielu znalazły swe potwierdzenie i uzasadnienie $\mathrm{w}$ księgach Starego Testamentu. Prorocy z bezwzględną pewnością przepowiedzieli, iż przyobiecany Mesjasz zstąpi na ziemię. Nie człowiekiem tylko, ale i Bogiem będzie (Iz. 40, 9), Ojcem przyszłego wieku $(9,6)$. Światłością narodom $(42,6)$, Światłością wielką mieszkającym w krainie cienia śmierci $(9,2)$, Przyjacielem ubogich i chorych $(25,4)$, Wodzem i Nauczycielem narodom $(55,4)$ i dobrym Pasterzem (Iz. 40, 11; Jer. 31, 10).

12) Wspomnienie to zostało odezytane na uroczystej akademii żałobnej, która ku czci ks. Archutowskiego urządził Wydział Teolog. U. J. w auli uniwersyteckiej dnia 18 marca $1950 \mathrm{r}$. 
Jezus był świadom swej nauczycielskiej misji. Już w mlodym wieku objawił się w tej postaci, gdy uczonym jerozolimskim głębokie zadawał $z$ prawa Mojżeszowego pytania, którymi ich wprawił w podziw i zdumienie. Matce zaś Swej, żalącej się z poczucia macierzyńskiej troski o Syna, którego trzy dni szukała, wprost oznajmił: ,, Nie wiedzieliście, ze w tych rzeczach, które są Ojca mego, potrzeba, abym był? ${ }^{6}$ (Łk 2, 49).

Gdy potem dojrzał do wieku, w którym mógł podług prawa wysląpić publicznie w roli nauczyciela, pouczył Apostołów: , Nie nazywajcie się nauczycielami, gdyz jeden jest nauczyciel wasz, Chrystus" (Mt 23, 10). Wprawdzie nie nauczał, ani nie wychowywał dzieci, gdyz uczniami Jego byli dojrzali ludzie. Niemniej jednak i oni powinni siebie uważać za braci wzglẹdem dzieci, które wychowują: ,Jeden jest nauczyciel wasz, a wy wszyscy braćmi jesteście“ (Mt 23, 8). Wraz z dziećmi sạ oni uczniami Boga: .Napisane jest u proroków: I będą wszyscy uezniami Bożymi“" (Jan 6, 45. Por. Iz. 54, 3).

Ewangeliczna myśl pedagogiczna o, ,jedynym Nauczycielu“ stała się punktem centralnym dziejów pedagogii chrześcijańskiej wszystkich czasów. Chrystocentryzm był zawsze trzonem jej celów i ideałów wychowawczych i na walorach personalistycznych Chrystusa wzorowali się nauczyciele i wychowawcy chrześcijańscy. Najwybitniejsi przedstawiciele katolickiej myśli pedagogicznej pozostawali zawsze na wyżynach swych genialnych osiągnięć niczym innym, jak tylko słabym odblaskiem osobowości pedagogicznej Chrystusa, ,jedynego Nauczyciela". Gdyby się z całokształtu pedagogii katolickiej odjęło Chrystusar wtedy jej siła dynamiczna spadłaby do zera ${ }^{1}$ ).

Już Klemens Aleksandryjski ${ }^{2}$ ) podaje, że ,Logos" jest jedynym nauczycielem i wychowawcą; był nim w Starym Zakonie i jest nim faktycznie z nastaniem Nowego Testamentu. Tylko On Sam nie potrzebuje zadnego nauczyciela i nikt w ogóle nie może być nauczycielem ,jedynego Nauczyciela“. Logos jest prawdziwym lekarzem i wychowawcą, a my wszyscy jesteśmy względem niego dziećmi i uczniami.

Laktancjusz ${ }^{3}$ ) wyjaśnia, dlaczego Chrystus jest ,,jedynym Nauczycielem". Nie może nim bowiem być, ani Bóg jako czysty Duch, ani téz sam tylko człowiek. Pierwszy z powodu swej duchowości i niewi-

1) Fr. de Hovre, Les Maîtres de la Pédagogie contemporaine. Paris, p. 7-8.

2) Des Clemens von Alexandreia Mahnrede an die Heiden. Der Erzieher Buch I. Aus dem Griech. übersetzt von O. Stählin, 1934, München, p. 214.

$\left.{ }^{3}\right)$ F. J. Knecht, Jesus Christus als höchstes Vorbild des Erziehers und Lehrers. (Lexikon d. Pädagogik, B. II (1913), p. 1014-1023). 
dzialności, jak również najwyższego i niedostępnego majestatu, drugi zaś wskutek swej niedoskonałości i braku potrzebnego autorytetu.

$\dot{S} w$. Augustyn ${ }^{4}$ ) przypomina też swemu diakonowi Deogratiasowi, że Chrystus powinien być ,.jedynym Nauczycielem“" w jego katechezach, które odbywa z katechumenami. Nie może zatem odstępować abytnio od obiektywnego, informującego opisu faktów biblijnych, aby Boski Nauczyciel żywo w nich występówał i serca słuchaczy do Siebie pociagał.

Do powyższych wywodów dodaje w swym liście ${ }^{5}$ ), co następuje: ,Ponieważ ciemnota naszego umysłu pod naporem namiętności jest wielka, dlatego nie było skuteczniejszego sposobu na sprowadzenie rodzaju ludzkiego na droge prawdy, ponad tajemnicze i cudowne wcielenie się odwiecznej Prawdy. Ona miała nas pouczyć przez dobre nauki i boskie czyny w dziedzinie wiary o tym, czegośmy sami własným nie mogli poznać rozsądkiem".

\section{Cechy pedagogiczne osobowości Chrystusa.}

Jeśli osobowość ludzka jest w swej treści niewyczerpalna, gdyż jej życie jest „przepaścią zawieszoną między dwiema innymi przepaściami, Bogiem i nicością", której głębi dokładnie zbadać nie można, to tym bardziej nie można zanalizować i określić należycie nadprzyrodzonej osobowości Chrystusa, choćby tylko na małym ordcinku jej przejawów pedagogicznych. $Z$ konieczności zatem ograniczyć sį̨ trzeba do zaznaczenia jej istoty, do określenia zasadniczych linii konturowych jej wewnętrznej struktury.

Podług psychologii dyferencjalnej, traktującej o odkrywaniu i ustaleniu typów psychofizycznych i duchownych wśród ludzi, przyjmuje się w osobowości pedagogicznej cechy ściśle pedagogiczne i cechy dydaktyczne. Do podstawowych pedagogicznych należą: moralny charakter, czynniki autorytetu, znajomości psychiki ludzkiej, miłość pedagogiczna, cechy pokory, naturalności i szczerości, takt pedagogiczny i pogodne usposobienie.

Wśród głównych cech dydaktycznych wymienia się dobrą i żywą inteligenčję, czynniki kontaktu pedagogicznego, wymowy, latwość

4) Sw. Augustyn, Pisma katechetyczne (Początkowe nauczanie katechizmu). Thum. X. Budzika, Poznań 1929, p. 3-71).

5) Epistola 118. 
intensywnego przė̇ywania nauczonych wartości i powołanie wewnętrzne do zawodu nauczycielskiego.

Jak świadczy Ewangelia, Jezus wywierał fascynujący wpływ zarówno na Swych przyjaciół i czcicieli, jak też największych wrogów. Ci ostatni muszą milczeć, gdy im śmiało rzuca w oczy wezwanie: ,Kto z was dowiedzie na mnie grzechu?" (Jan 8, 46). W Nazarecie prowadzą Go na szczyt góry, ażeby zrzucić Go z niej w przepaść, lecz Qn

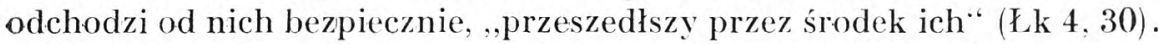
W Jerozolimie porwali już kamienie, ażeby Go jako bluźniercę zabić, lecz i tym razem ulegli Jego urokowi indywidualnemu; Mistrz wyszedł cało $z$ ich reski (Jan 10, 31-39).

Innym razem faryzeusze posłali swych oprawców do Chrystusa. spośród ludzi bezwzglednie sobie oddanych, aby Go pochwycili. Lecz i oni nie mogli nie ulec czarowi Jego osobowości, nie targnąwszy się Nań (Jan 7, 32;45-46). Gdy w końcu przyszła już zapowiadana przez Niego godzina, aby był wydany w rece grzeszników (Mk 14,41), kiedy żołnierze rzymscy i strażnicy świątyni porwali się na Chrystusa, aby Go uwięzić, to jeszcze i w tym tragicznym dla Niego momencie na wypowiedziane do nich słowa: ,Jam jest", cofnęli się w tył i padli na ziemię $(\operatorname{Jan} 18,6)$.

Jednakże podług ,psychologii tłumu“ (Psychologie des foules) ${ }^{6}$ ) innym jest człowiek w tłumie, a innym indywidualnie, $z$ dala od niego. Będac istota wysoce sugestywną, ulega psychozie zbiorowej swego środowiska społecznego. Krytyczniej zaś odnosi się do prestiżu drugich pod refleksem swej samodzielności. Wpływowi jednak osobniczego uroku Chrystusa poddaja się Jego nieprzyjaciele. Stojący z dala od nastrojów tłumu i owszem im sie nawet przeciwstawiający Piłat, prokurator rzymski w procesie Chrystusa, publicznie oświadcza Jego oskarżycielom: ,Ja w nim nie znajduje winy" (Jan 19,6) i nazywa Go sprawiedliwym: „Nie winien ja krwi tego sprawiedliwego" (Mt 27, 24). I Judasz Iszkariot wyznał w końcu zrozpaczony: ,Zgrzeszyłem, wydawszy krew sprawiedliwa“" (Mt 27, 4).

Rezonansem ludu palestyńskiego, pozostającego pod olbrzymim wpływem asobowości Chrystusa, były jego liczne, tysiączne rzesze, które z entuzjazmem się do Niego garnęly, zwłaszcza w początkach publicznej działalności mesjańskiej. Z owych właśnie tłumów podniosły się typowe dla ich Nauczyciela okrzyki radosne: „Błogosławiony $\dot{z} y$ wot, który cię nosił i piersi, któreś ssał" (Łk 11, 27).

(i) Le Bon Gustave, La psychologie des foules (Fr. Hovre, op. c. p. $506-611$ ) 
Ze strony urzędu nauczycielskiego pierwotnego Kościola św. Piotr Apostoł, pierwszy zastępca Chrystusa na stolicy rzymskiej, wydał autorytatywny sąd o asobowości Chrystusa. „On grzechu nie uczynił, i zdrada nie znalazła się w ustach jego. Gdy mu złorzeczono, nie złorzeczył; gdy cierpiał, nie odgrażał się pomstą, ale oddawał się temu, co sprawiedliwie sądzi“ (1 Piotr 2, 22-23); ,przeszedł czyniąc dobrze“ (Dz. Ap. 10, 38). Św. Paweł ujął postać duchową Jezusa zwięźle słowami: „Okazała się dobrotliwość i ludzkość Zbawiciela naszego Boga" (Tyt 3,4$)$.

Skoro osobowość Boża ,jedynego Nauczyciela“ roztaczała dokoła Siebie olśniewające wartości i dobra najwyższe Swej psychiki to z punktu czysto ludzkiego i psychologicznego do niej podchodząc, należy tylko stwierdzić, ̇̇e ona była wyposażona w najliczniejsze i najwspanialsze walory pedagogiczne i dydảktyczne. Nawet największe talenty ludzkie w dziedzinie wychowania i nauczania nie mogą ich wszystkich posiadać, gdyż ich poszczególne zespoły spójne wykazują pomiędzy sobą wewnętrzne sprzeczności, które w jednym osobniku razem obok siebie istnieć nie mogą.

Szukając dlą przeżyciowej warstwy pedagogicznej osobowości Chrystusa odpowiednika w strukturze psychofizycznej, wrodzonej, należałoby przypuszczalnie wśród wielu możliwych tego rodzaju typów wskazywać na typ "fascynujący" we fizjognomicznej typologii francuskiej E. Ledos'a '). Z góry jednak zaznaczyć trzeba, że istnieje tylko prawdopodobieństwo korelacji w strukturze wewnętrznej człowieka pomiędzy jego psychiką a predyspozycjami anatomiczno-organicznymi. Psychika natomiast zmysłów zewnętrznych i wewnętrznych i dyspozycje temperamentu łączą się strukturalnie, wspólzależnie, w jedną zwartą całość funkcjonalną ze somatycznym układem organizmu.

Typ fascynujący wymienionej typologii określa się owalną formą twarzy i czaszki albo pośrednią między czworoboczną a owalną. Twarz jest proporcjonalna, dostojna, o rysach wysokiego urodzenia. W strukturze dyspozycjonalnej psychicznej odznacza się potencjami znakomitych uzdolnień: bystrością umysłu, zdumiewającą pamięcią, wszechstronną inteligencją, niezwykłą subtelnością i wspaniałomyślnością uczuć, oraz niczym niepowstrzymaną wolą. $Z$ aspektu na te wrodzone wartości jednostka tego typu, jak zauważa jego odkrywca Ledos, wywiera fascynujący wpływ na swe otoczenie. Zdumiewa $\mathrm{i}$ w podziw wprawia swą geniạlnością, olśniewa i podbija umysły i pociąga ku

7) E. Peillaube, Caractère et Personnalité, Paris, p. 32. 
sobie tajemniczą więzią serca ludzkie. Nie mniej jednak grozi tej uprzywilejowanej z urodzenia jednostce niebezpieczeństwo załamania się na szczytach powodzenia, jeśli tylko pozwoli unieść się pysze i przesadnemu poczuciu własnej godności (Napoleon, Aleksander Wielki).

Jezus Chrystus, królewski potomek rodu Dawida, ,pierworodny wszelkiego stworzenia" (Kol 1, 15) zdaje się zbliżać w swej ludzkiej naturze, na podstawie przejawów życiowych, składających się na pasmo jej obiektywacyj opisanych w Ewangeliach, do powyższego typu fizyczno-psychicznego osobowości ludzkich. Zgodnie ze świadectwami Ewangelistów jest On mężem żelaznej konsekwencji i stalowej energii i równocześnie subtelny i delikatny, jak najczulsza matka. Najgłębsza i niepojęta pokora łączy się w Nim z poczuciem najwyższych, ucieleśnionych w Nim wartości personalistycznych i posiadanego Przezeń ponadludźkiego autorytefu. Od męża, który żyje w niedostępnym z Bogiem zjednoczeniu, i do którego ramion cisną się dzieci i wszelkiego rodzaju biedni, promieniuje majestat, który jak wiadomo i nieprzyjaciół onieśmiela, krępuje i ubezwładnia.

Chrystus Pan był też najmędrszy spośród wszystkich ludzi, a przed wielkością Jego umysłu chylili czoła także czyhający zawzięcie na Jego zgubę. ,Tak wielkich twórczych słów i tak szczytnych prawd, jakie obwieścił światu, nie wypowiedziała nigdy żadna jednostka ludzka, ani też ludzkośé wzięta we wszỳstkich swoich najgenialniejszych i najszlachetniejszych przedstawicielach". Wprawdzie nie wszystka treść Jego nauk była na wskróś oryginalna, gdyż w Swe myśli i światopoglądy włączał takíe najszczytniejsze prawdy i zasady filozoficznych systemów moralnych innych kulturalnych narodów, a szczególniej ze Swego środowiska spolecznego. Niemniej jednak owe wytwory wewnętrzne ducha ludzkiego On poszerzał, pogłębiał i opatrywał gwarancją Swego nieomylnego autorytetu ${ }^{8}$ ).

Podkreślenia godne są jeszcze inne cechy pedagogiczne ,,jedynego Nauczyciela“. Oto wszystkich ludzi otaczał bezwzględnie szacunkiem, czym odróżniał się biegunowo od Swego otoczenia. Nie tylko nie odwracał się od dzieci i dojrzałych pod względem fizycznym, psychicznym i duchowym małowartościowych, podług oceny przeciętnych ludzi, alc wprost przeciwnie, nimi szczególniej się interesował i ku nim się skłaniał. ,Ta jest wola tego, który mnie posłał, Ojca, żebym z tego wszystkiego, co mi dał, niczego nie stracil, ale żebym to wskrzesił

$\left.{ }^{8}\right)$ Arcyb. Bilczewski Józef, Listy Pasterskie. T. III. Lwów, Bibl. Rel. 1924, p. $87-225$. 
w ostatni dzień (Jan 6, 39). ,Nie potrzeba zdrowym lekarza, ale źle się mającym... bom nie przyszedł wzywać sprawiedliwych, ale grzeszników" (Mt 9, 12).

Z szacunkiem dla ludzi łączył niezrównaną cierpliwość i wyrozumiałość względem nich, z racji popełnianych przez nich błędow na drodze ich nowego życia. Gdy np. podczas jednej podróży do Jerozolimy mieszkańcy pewnego miasteczka samarytańskiego nie chcieli Jezusowi udzielić gościny, za co Apostołowie Jakub i Jan domagali się od Niego spalenia ogniem z nieba tej osady, usłyszeli od Misłrza słowa ostrej nagany: „Nie wiecie, czyjego ducha jesteście. Syn człowieczy nie przyszedł gubić dusze, ale je.zbawiać“ (Łk 9, 52-56). Náwet Judasza zdrajcę, który Go wydał w ręce wrogów, w krytycznym dla Siebie momencie nazwał Swym ,przyjacielem“ (Mt 26, 50).

„Jedyny Nauczyciel" i Zbawca wychował chrześcijańskie charaktery świętością Swego życia, najszlachetniejszą czystością Swych intencji i niesłabnącą gorliwością zbawiennych czynów w spełnianiu Swego posłannictwa. W przeciwieństwie do nauczycieli-faryzeuszów, których osobiste życie nie szło w parze z głoszoną przez nich nauką, Jezus niczego nie wymaga od Swych uczniów, czegoby Sam przedtem najdokładniej w życiu nie stosował.

Najpiękniejszą cechą pedagogicznej osobowości Chrystusa była Jego bezgraniczna miłość ku ludziom, Swym uczniom i wychowankom. ,Większej miłości nikt nie ma nad tego, który duszę swą kładzie za przyjaciół swoich" (Jan 15, 13). Miłość pedagogiczna jesi osobliwą formą miłości religijnej i społecznej. Jak każdej innej szlachetnej miłości, jest jej celem zaspokojenie rozlicznych potrzeb stawającej się młodej osobowości i ubogacenia jej we wszystkie dobra, którymi rozporządza dojrzała osobowość nauczyciela. Celem miłości pedagogicznej Chrystusa względem ludzi było przyodzianie ich w najmożliwiej maksymalne człowieczeństwo i dziecięctwo Boże. Punktem wyjścia w tej pracy było unadnaturalnienie natury ludzkiej łaską uświęcającą: ,,jakby Bożą duszą naszej duszy" (Bilczewski) : ,,Ja przyszedłem, żeby (owce) żywot miały i obficie miały". (Jan 10, 10). Metą udoskonalenia życia, do której osiągnięcia olbrzymich i wytrwałych potrzeba wysiłków, było odtworzenie w sobie charakteru Chrystusa, ideału doskonałego chrześcijanina. „Których przejrzał, tych i przeznaczył, aby byli podobni obrazowi Syna Jego" (Rzym 8. 19).

Każda osobowość pedagogiczna wyraża się własnym -stylem, swoistym oryginalnym obliczem pedagogicznym, zależnie od swych 
uzdolnień, cech swego wszechstronnego środowiska, selekcyjnych reakcyj na jego podniety i od wpływu czynnika nadprzyrodzonego. Nie istnieje zatem jakiś jeden typ ludzi szczególniej uprzywilejowany z natury do zawodu i stanu nauczycielskiego, lecz przeciwnie jest ich więcej równie dobrych w granicach swych indywidualnych typów.

Boski Nauczyciel pomimo ucieleśnienia w Sobie idealnych cech ogólnoludzkich w natężeniu najwyższym, odznaczał się jednak pewnymi cechami, które wyprzedzały w Nim wszystkie inne. Na nich też usiłują oprzeć próby charakterystyki Jezusa. Znamienne jest w tym aspekcie polecenie Jego, aby Go naśladować w pokorze: „Uczcie się ode mnie, żem jest cichy i pokornego serca, a znajdziecie odpoczynek duszom waszym" (Mt 11, 29).

Lecz żaden typ psychofizyczny, czy przeżyciowy (światopoglądowy) nie zdoła ogarnąć ramami swej struktury niezwykłej i niezrównanej pedagagicznej osobowości Chrystusa. Osobowość bowiem człowieka syntetycznie ujęta, wrodzona i nabyta posiada kilka warstw w przekroju. Pierwszą z nich oglądaną od środowiska stanowią socjologiczne, przeżyciowe na tle otoczenia skutki jego kulturalnych czynności. To są obiektywacje, wyrazy zewnętrzne jego wartości wewnętrznych, wykształcenia, charakteru i osobowości, zobiektywizowane w wytworach kultury materialnej i duchowej. Drugą warstwę tworza dyspozycje potencjalne, zdolnościowe i pożądawcze, które tkwią w psychologicznej sferze osobowości i odziedziczone zostały po przodkach. One właśnie ujawniły i rozwinęły się w obiektywacjach nadbudowy życia podług przewodnich ideałów.

Przez tę warstwę wnikamy do trzeciej, charakterologicznej, uformowanej głównie przez wychowanie i samowychowanie pod wszechstronnym wpływem peristazy, integralnego otoczenia. $Z$ podłoża tych czynników twórczych osobowości jednostka jest wiernym modelem swego zawodu, prawdziwa kopią swego środowiska, dzieckiem duchowym swego narodu, warstwy społecznej i swej epoki.

W końcu człowiek może się wznieść do czwartej, najwyższej warstwy osobowości idealnej, duchowej, która osadza się wprawdzie na dyspozycjonalnej, charakterologicznej i socjologicznej, lecz swymi najwyższymi wartościami, które w niej urzeczywistniono, przewyższa je wszystkie. To warstwa metafizyczna, w której dominuje czysty byt o cechach ogólnoludzkich, wiecznych, ponadczasowych i ponadprzestrzennych. Kto ją posiadł, przeżył i zasymilował, przyswoił sobie naj- 
piękniejszą strukturę duchową człowieka wiecznego, najwspanialsze dzieło kultury duchowej, sztuki życia na ziemi ${ }^{9}$ ).

Chociaż Chrystus Pan wykazywał w swej somatycznej i psychicznej strukturze biopsychiczny, etnologiczny i rasowy typ Izraelity galilejskiego, to jednak psychika duchowa jego osobowości pedagogicznej nie była ani galilejska, ani ogólnożydowska, ani grecka, ani rzymska, ani w ogóle antyczna, czy nowożytna. Odzwierciedlił bowiem w swej ludzkiej naturze pełny typ wiecznego, powszechnego człowieka, ideał całej ludzkości, ,koronę rozumnej natury" (Oryginel) ${ }^{10}$ ).

\section{Cechy dydalityczne osobowości Chrystusa.}

Już we wstępie zaznaczyć należy, że metoda nauczania Chrystusa była zawsze przedmiotem godnym podziwu. ,Nigdy tak człowiek nie mówił, jak ten ezłowiek“ (Jan 7, 46), odpowiadają słudzy świątyni członkom najwyższego sądu, z którego polecenia mieli Jezusa przemocą pojmać. Metoda nie była szablonowa, ale urozmaicona zależnie od pojętności i przygotowania słuchaczy. Wykształconemu i pozytywnie do nowej nauki usposobionemu Nikodemowi już w początkach Swego publicznego wystąienia pozwala wniknąć do głębi postaci nowego Królestwa Bożego na ziemi. W rozmowie ze Samarytanką przy studni Jakubowej opiera naukę o Swym mesjaństwie na glẹbokiej znajomości psychiki duchowej mieszkanki samarytańskiej. Krótko potem przedstawia się w Nazarecie w tematycznym przemówieniu, do którego główną myśl zaczerpnął z Pisma Świętego i rozwinął ją zastosowaniem do Siebie jako Mesjasza.

Apostołów, których wychowywał w specjalnej szkole, stopniowo prowadzi do zrozumienia własnej osobowości i istoty nowej religii. $\mathrm{Z}$ początku uczył ich o Mesjaństwie, potem o Synostwie Bożym, a gdy się z tą wiarą zżyli, objawił im szczegóły o Swej męce, śmierci, zmartwychwstaniu, wniebowstąpieniu i wtórnym przyjściu przy końcu świata. Stopniowo także prowadzi do wiary w Swe Bóstwo Martę z Betanii przed wskrzeszeniem jej brata Łazarza, jak również człowieka ślepourodzonego po uleczeniu go ze ślepoty.

Osobny system wychowania stosował wobec mas ludu izraelskiego. Te były wprawdzie religijne, lecz $\mathrm{w}$ duchu światowym, narodowo-po-

9) Hans Prinzhorn, Um die Persönlichkeit, Heidelberg 1927, p. 86-93.

$\left.{ }^{10}\right)$ Arcyb. Bilczewski Józef, Listy Pasterskie t. IlI, Lwów 1924, p. 207. 
litycznym, pod przemożnym wpływem swych duchowych przewódców. Dlatego w szkole wychowania ludu dąży do pogłębienia jego religijności, czego największym dowodem jest Kazanie na górze. Po tej też linii idą po sobie na przemian potężne cuda, głębokie nauki moralne, piętnowania niemoralnego życia starszyzny żydowskiej i odciągania od niej rzesz. ludu. Swoją jednak osobę utrzymuje w cieniu, zakazując np. rozgłaszać cuda i unikając wszystkiego, co by wskazywać mogło na polityczny charakter jego publicznych wystąpień.

Niemniej jednak posługuje się autorytatywnym sposobem nauczania, w którym Swój autorytet nauczycielski wynosi ponad powage ksiąg moralnych Starego Testamentu. Wymownie o tym świadcza Jego słowa z Kazania na górze: „Słyszeliście, iż powiedziano: Będziesz miłował bliźniego twego, a będziesz miał w nienawiści nieprzyjaciela twego. A ja wam powiadam: miłujcie nieprzyjacioły wasze, dobrze czyńcie tym, którzy was mają w nienawiści... Słyszeliście, iż powiedziane było starym: Nie będziesz zabijal, a ktoby zabił, będzie winien sądu, a ja wam powiadam, iż każdy który się gniewa na brata swego, będzie winien sądu" itd. (Mt. 5, 43-44, 21-22).

We wszelkim nauczaniu, jak też refleksyjnym myśleniu, ruch myslowy idzie w podwójnym kierunku: od danych częściowych, rzeczy znanych, konkretnych i bliskich, do rzeczy nieznanych, nieobecnych, dalekich i w końcu do jakiejś całości, ogólnego pojęcia, wyrażonego w pewnej wiążącej je zasadzie. To ruch indukcyjny, w którym dobiera się tylko fakty dla danej zasady ważne, w miarę możności typowe, a wyklucza się wszystko inne, co dla tej sprawy jest nieważne, lub mniejsze ma znaczenie.

Stałą tendencją metody indukcyjnej jest uogólnianie podawanych wiadomości, w których analizowane pojęcie przechodzi coraz bardziej z niejasności i wieloznaczności, do określoności i ścisłości znaczenia, zdeterminowanego ostatecznie w definicji. Ona magazynuje niejako pod szatą zwięzłych, a ważkich słów wielkie bogactwo wiedzy abstrakcyjnej, zaczerpniętej $z$ indukcji.

Lecz tak, jak woda spływa naturalnie na dół siłą swego ciążenia ku ziemi, podobnie też zasada jest ideą ruchu myślowego, a przez korelacje $z$ wolą i uczuciem także wolitywnego i emocjonalnego, inerwującego zarówno psychikę zmysłową i duchową, oraz fizjologiczne podłoże życia ludzkiego. Jeśli prawda wiary wystąpiła jasno i zrozumiale pod szatą obiektywwnej definicji, musi przemienić się jeszcze 
w psychice duchowej uczniów w subiektywną, umiłowaną prawdę życiową, w stałe przekonanie, w zasadę normatywną.

Do tego właśnie celu prowadzi dedukcja, ruch myślowy wsteczny od zasady do jej zastosowań przeżyciowych, od ogólnych abstrakcyjnych pojęć do konkretnych przejawów życia, w kierunku sprawdzenia tej zasady i potwierdzenia jej prawdziwości efektywnością w konkretnym życiu. Dedukcja ustala nie tylko zasady, lecz także je rozwija i doprowadza do pełnego i całkowitego znaczenia. $Z$ tego téz powodu formuly dedukcyjne, definicje nie są w nauce celami same przez się, lecz pośredniczącymi funkcjami ułatwiającymi rozwinięcie pojęcia i wszechstronne poznanie jego treści, oraz praktyczne zastosowanie go do konkretnych faktów w różnych sytuacjach życia.

Uogólniania zatem i zastosowania leżą w jednostce metodycznej lekcji szkolnej blisko siebie. Ogólne normy dążą do spontanicznego zaktualizowania się w czynach. Jak proces myślenia, podobnie i lekcja szkolna zaczyna i kończy się w sferze konkretów. Od synkretyzmu życia uczniów jako punktu wyjścia począwszy, idzie poprzez pogląd wykład indukcyjny do wyjaśnienia dedukcyjnego i kończy swój przebieg na zastosowaniu, czyli przeżyciu $\mathrm{i}$ czynie religijnym. Prawda wiary wymaga oddania się jej, przejęcia się nią i przeżycia jej wartości, jeśli ma się stać trwałą normą życia.

Z powyższego wynika, że postawa uczniów podczas lekcji szkolnej powinna być zarówno receptywna, jak i produktywna, kontemplacyjna i aktywna. Momenty kontemplacji przechodzi podczas wykładu, opowiadania $w$ przeżyciach religijno-moralnych, estetycznych, patriotycznych i społecznych. Zaś momenty produktywne przeżywa uczeń w pracy samodzielnej, w wysiłkach twórczych w rozwiązywaniu problemów, sytuacji realnych, stwarzanych przez nauczyciela w szkole i w odpowiedziach na wszelkiego rodzaju pytania zadawane mu przez nauczyciela.

Zgodnie zatem ze współczesnymi zasadami nauczania, opartymi na klasycznych stopniach formalnych Herbarta Jana i Dewey'a Jana, dla których podłożem twórczym stały się osiągnięcia psychologicznodydaktyczne ich wielkich poprzedników Arystotelesa, Komeńskiego i Pestalozziego, schemat lekcji szkolnej przechodzi przez pięć stopni formalnych. Punktem wyjścia jest synkretyzm rzeczywistości aktualnego zawsze prądu życia, po którym następuje określenie problemu, sytuacji realnej, pewnej trudności do wyjaśnienia i rozwiązania. W następnym punkcie wzbudza się zainteresowanie się potrzebą tego zagad- 
nienia, po czym jest podejmowanych szereg próbnych czynności ze strony uczniów w związku z powstałą trudnością, celem jej usunięcia. Gdy ich wysiłki są daremne, wkracza w końcu nauczyciel z czynnością przystosowaną, którą rozwiązuje problem i stwarza sytuację idealnąą $\left.{ }^{11}\right)$.

Po tym dłuższym wstępie, w którym poddano szczegółowej analizie wszystkie stopnie formalne jednostki metodycznej, spróbujmy na podstawie ich struktury ułożyć schemat pięciostopniowy w prakatechezie Chrystusa o Mesjaszu, którą odbył ze Samarytanką koło Sychar, w okresie powielkanocnym pierwszego roku Swej publicznej działalności.

Punktem wyjścia jest tu synkretyzm życiowy. Uczniowie mianowicie poszli do miasta po żywność, a Nauczyciel siedzi zgłodniały przy studni Jakubowej. Niebawem przychodzi niewiasta po wodę. „Daj mî pić“ (Jan 4, 7), rzecze do niej Jezus. ,Jakże ty będąc Żydem, prosisz pić u mnie, niewiasty samarytańskiej“ $(4,9)$, odpowiada niewiasta. $Z$ kolei stwarza Nauczyciel sytuację realną, daje problem do rozwiązania. ,Gdybyś ty poznała dar Boży i kto jest, co ci mówi: Daj mi pié, tybyś go raczej poprosiła, a on dałby ci wody żywej“ $(4,10)$.

Potrzeba i zainteresowanie się człowiekiem, którego spotkała, oraz tajemniczą wodą, o której mówił, wzrasta u Samarytanki i do najwyższego dochodzi natężenia po dalszych słowach Chrystusowych: ,Każdy, kto pije z tej wody, znów będzie pragnąl, lecz kto napije się wody, którą ja mu dam, nie będzie pragnął na wieki“" $(4,14)$. Odpowiada bowiem natychmiast samorzutnie: „Panie! daj mi tej wody, abym nie pragnęła i czerpać tu nie przychodziła“ $(4,15)$. Gdy zaś poznała, ’̇e Jezus jest prorokiem, gdyż odkrył jej tajne grzechy, występuje $z$ nowa potrzebą dowiedzenia się, gdzie należy Boga chwalić, w Jeruzalem, ezy na górze Garizim? Przy końcu rozmowy wyłania się u niej nowa potrzeba, zainteresowanie się tajemniczą osobą mającego przyjść Mesjasza.

Samarytanka używa też jako uczennica czynności próbnych do rozwiązania trudnej sytuacji, w której się znalazła. Co to za dar Boży, który spotkała? Co za woda ku żywotowi wiecznemu? W swych dociekaniach popełniła kilka błędów, na które Nauczyciel zezwala. Oto perswaduje Mu: ,Panie, i czerpać czym nie masz, a studnia jest głęboka, skądże więc masz wodę żywą?“ $(4,11) \ldots$,Czy większy jesteś, niż ojciec nasz Jakub?“ $(4,12)$. ,Panie! daj mi tej wody, abym nie pragnęla

11) John Dewey, Jak myślimy (How we think). Tłum. Z. Bastgen, Lwów, p. 109-128; Z. Mysłakowski, Nauczanie żywe a podręcznik szkolny, Lwów 1936. 
i czerpać tu nie przychodziła“ $(4,15) \ldots$, ,Ojcowie nasi chwalili (Boga) na tej górze, a wy powiadacie, że Jeruzalem jest miejsce, gdzie chwalić potrzeba“ $(4,20)$.

Wszystkie próby niewiasty rozwiązania problemu okazały się czynnościami nie celowymi i dlatego w tok, ,katechezy" wkracza z czynnością przystosowaną Sam Nauczyciel. Gdy bowiem Samarytanka oświadczyła, że czeka na Mesjasza i na Jego objawienie, rzecze jej Jezus: ,,Jam jest, który mówię z tobą" (Jan 4, 26).

Dialogowa forma katechetyczna, zastosowana w rozmowie $z$ niewiastą Samarytańską obfituje, jako szkic religijno-dydaktyczny, w momenty intelektualistyczne i przeżyciowe, naprowadzające i wyjaśniające, indukcyjne i dedukcyjne. Obydwaj partnerzy przygodnego procesu nauczania biorą w nim intensywny udział i odnoszą z niego obopólny pełny sukces. Nie tylko bowiem Samarytanka uwierzyła w Chrystusa, ale również z miasta Sychar ,,wielu Samarytanów uwierzyło weń dla słowa niewiasty, świadezące: że mi wszystko powiedział, com tylko uczyniła" (Jan 4, 39).

Szereg innych indywidualnych i ogólnych prakatechez Chrystusa możnaby w powyższy sposób zanalizować. We wszystkich zaś przewodzi indukcja w niezrównanych opowiadaniach, przypowieściach, przykładach $z$ przyrody i życia społecznego i indywidualnego, oparta na nadprzyrodzonej znajomości przepastnych głębin psychiki ludzkiej i na treściach Pisma Świẹtego.

Indukcję uzupełnia dedukcja. Paradoksy Kazania na górze, najpiękniejsze ziarna nauki ewangelicznej, często nie w sensie literalnym, ale duchowym rozumiane, oraz inne maksymy, przekazane w mowach Chrystusowych szczególniej przez św. Mateusza i św. Jana, wykazują najwięcej treści dedukcyjnej. Wystarczy dla przykładı przytoczyć ich kilka, aby się zorientować, jaką one spełniają rolę pod aspektem dydaktycznym. ,Kto miłuje duszę swą, traci ją, a kto nienawidzi duszy swojej na tym świecie, ku żywotowi wiecznemu zachowa ją:" (Jan 12, 25); „Kto nie jest ze mną, przeciw mnie jest, a kto nie zgromadza ze mną, rozprasza“ (Łk 11, 23); ,.Wy jesteście solą ziemi. A jeśli sól zwietrzeje, czym solona będzie. Na nic się więcej nie przyda, jeno aby była precz wyrzucona i podeptana przez ludzi“ (Mt 5, 13) ; , Jam jest światłość świata: kto za mną idzie, nie chodzi w ciemności, ale będzie miał światłość żywota" (Jan 8, 12) itd.

Pod szatą kilku słów czy zdań magazynuje dedukcja w maksymie, ezy definicji wielkie niekiedy bogactwo wiedzy i czyni człowieka przez 
utrwalenie jej w pramięci językowej, słownej stałym posiadaczem wiedzy i jej wiernym propagatorem. W ten sposób dokonuje się psychologiczne sprzężenie jednostki z prawdą, zasadą religijną, która w skomplikowanym prądzie codziennego życia utrzymuje ją ustawicznie na drodze, zdeterminowanej do ostatecznego celu. Przyswojonej pamięci i zasymilowanej maksymy wiary, ujęlej w ramy formuły dydaktycznej nie zastąpią ani wykłady (poglądy) ani rozumowania ani przeżycia i nawet same czyny religijne, choćby były często powtarzane. Wszystkie bowiem są przejawami przejściowymi płynącego wciąż życia, które z czasem pogrą̇̇ą się w nieświadomości. Stąd rozumiemy jasno, dlaczego dydaktyczna forma dedukcji znalazła też odpowiednie miejsce w metodzie ,jedynego Nauczyciela“.

Bezpośredni kontakt ze słuchaczami utrzymywal On za pomoca pytań. Jedne z nich były sprawdzające. Ich celem jest pobudzić uczniów do wspóṕpracy z nauczycielem i przekonać się, czy uczniowie go słuchają i rozumieją. Czynił to również Pan Jezus pod Cozareą Filipową. Juź wiele razy słyszeli Apostołowie z ust Mistrza, że jest Mesjaszem, Synem Bożym, a te stowa potwierdzały liczne cuda, których byli świadkami. Chcąc doświadczyé ich wiary i owoców Swej nad nimi pracy, zapytał ich:, ,A wy kim mnie być powiadacie? Odpowiadając Szymon Piotr, rzekł: Ty jesteś Chrystus, Syn Boga żywego" (Mt 16, 15-16).

Drugie pytania były egzaminacyjne. Pewien np. faryzeusz postawił Jezusowi pytanie, co ma czynić, by dostąpić żywota wiecznego? ,A on rzekł do niego: W Zakonie co napisane? jakże czytasz? On odpowiedziawszy rzekł: Będziesz miłował Pana, Boga twego, z całego serca twego i z całej duszy twojej i ze wszystkich sil twoich i z całej myśli twojej, a bliźniego twego, jako samego siebie. I rzekł mu: Dobrześ odpowiedział; to czyń, a będziesz żył" (Lk 10, 25-28).

Inne pytania były naprowadzające. Zwykle wymagaja one wielkiego wysiłku od ucznia, który musi skupić uwagę, aby rozwiązá dane mu w nich zagadnienie. Boski Nauczyciel wymagał przy nich niekiedy największych do pokonania trudności wysiłków. Faryzeuszom np., którzy chcieli Go pochwycié na słowie, takie postawił pytanie: "Co sądzicie o Chrystusie? Czyim jest synem? Rzekli mu Dawidowym. Rzekł im: Jakże tedy Dawid w duchu zowie go Panem, mówiąc: Rzekł Pan Panu nemu: Siądź po prawicy mojej, aż położę nieprzyjaciół twoich podnóżkiem nóg twoich? Jeśli tedy Dawid zowie go Panem, jakíe jest synem jegso? A żaden nie mógł mu odpowiedzieć slowa" (Mt 22, 42-46). 
Jeszcze inne pytania były retoryezne; one ożywiają mowe i czynia ją bardziej bezpośrednią. Polecając np. wielką ufność w modlitwie względem Pana Boga, zwraca się Zbawiciel z takim zapytaniem do Swych słuchaczy: ,Któryż $z$ was, jeśliby go prosil syn jego o chleb, poda mu kamień? Albo jeśli prosi o rybę, poda mu wèja?" (Mt 7, 10).

Chrystus Pan doceniał także w nauczaniu znaczenie częstego powtarzania omówionego już przedmiotu. Często np. uczył o obowiązku i konieczności wiary, pokory, modlitwy i bojaźni przed Bogiem. Wiele też razy powraca do nauki o rzeczach ostatecznych.

Jeszcze godne uwagi w metodzie nauczania Chrystusa sa te cechy, że forme podająca! wykładową, zmieniał na dialogowa, pytająca, i na metodę form połączonych i na odwrót. Nauczał przy tym krótko, prosto i poglądowo, w tonie miłym i pociagającym, w atmosferze radosnego spojrzenia na świat i życie, tak, że nawet nieżyczliwi Mu Nazaretanie „przyświadczali mu i dziwili się wdzięcznym słowom, które wychodziły z ust jego" ( $九 k$ 4, 22). Do natki przygohowy wat sį modlitwą i odbywał ją z świętą powagą, godnością i dokładnością, z poczuciem posłannictwa, po myśli słów Ewangelii: ,Źaden, który rękę swą przykłada do pługa, a ogląda się wstecz, nie jest sposobny do królestwa Bożego" (Łk 9,62).

Kalwaria

Ks. JÓZEF DAJCZAK

\section{MISTYRA HEBRAJSKA \\ U Św. PAWŁA I W APOKALIPSIE Św. JANA}

Celem niniejszego, ariykułu jest zwrócenie uwagi na pewien problem, na ogól nieznany, a jednak mający niezmierne znaczenie dla egzegezy Pisma św. Jest ninı starożytna tradycja mistyczna hebrajska.

Dlaczego szukać rozwiązania różnych zagadnień, związanych z egzegeza Nowego Testamentu, w pojęciach mitologiczno-religijnych babilońskich i hellenistycznych, skoro można ju znaleźć jedynie na tym gruncie, na którym księgi Nowego Testamentu powstały, t. zn. w rozległej tradyicji hebrajskiej, a szczególnie w tradycji mistycznej? Nieuwzglednianie tej tradyoji prowadzi do interpretacji całkiem błędnych, do których należy np. interpre- 